\title{
Development of Lifelong Education in the National Sports
}

\author{
Ming Hou \\ Wuhan University, Wuhan City, Hubei Province, China
}

How to cite this paper: Hou, M. (2017). Development of Lifelong Education in the National Sports. The Educational Review, USA, 1(2), 43-46. http://dx.doi.org/10.26855/er.2017.02.005

Corresponding author: Ming Hou, Wuhan University, Wuhan City, Hubei Province, China.

\begin{abstract}
With the deepening of physical education reform in colleges and universities in China, especially in recent years, some achievements have been made in the teaching reform of physical education in colleges and universities. In this paper, through the methods of literature, on-the-spot visit and so on, it makes a deep analysis on the reform of college P.E. teaching and its influence on lifelong education, aiming at making a contribution to the improvement of the college P.E. teaching system and the development of lifelong education in the national sports.
\end{abstract}

\section{Keywords}

Lifelong Education, College P.E., National Movement

\section{Introduction}

It is the ultimate goal of education and teaching in China to train all-round developments of modernized talents. The university is also a part of physical education, and it is very important to train modern talents. To cultivate students ' lifelong sports consciousness and ability is the most urgent task in colleges.

\section{The Relationship between Lifelong Physical Education and Physical Education in Universities}

\subsection{Analysis of the Concept of Lifelong Physical Education}

The idea of life-long sports is a new concept beginning in the 90's, and a new trend of sports reform. Life-long sports, as the name implies, refers to a person's lifelong physical exercise and physical education. And the contents of lifelong sports cover two parts: first, it refers to that, at the beginning and the end of life, as to the physical exercise with a clear purpose, physical education is an inseparable part of its life; and the second is that, the difference between it and the 1st is that it can take part in lifelong physical exercise, at which time, the purpose of sports is related to the nurture of education, and its goal is the result of the concept of lifelong sports. In addition, the concept of lifelong physical education, the so-called lifelong sports awareness, refers to people's lifelong physical exercise understanding, cognition, habits and abilities. The concept of lifelong sports is not only a kind of idea, a kind of thought, but also a requirement of the times. The training of lifelong physical education covers a wide range of aspects including health awareness, sports knowledge and sports skills (Lin \& Ke, 2008).

\subsection{Essential Elements of Lifelong Physical Education}

Health awareness: Physical health is everyone's pursuit. As pointed out by Zeng Mingwen, "Health is not only a concept without disease or infirmity, but also a good general term for physical, mental health and social adaptability." In other words, peo- 
ple should have the awareness of participating in sports activities actively, and in sports activities find their own interests in sports, and then form a good habit of exercising consciously.

Professional knowledge: general knowledge of physiology and health, sports and humanities, and physical training. Physical knowledge is through learning to understand the physiological structure of human body and the law of human physiology development. On this basis, understand the promotion of sports activities to human body health, and then have a plan for the purpose of physical exercise, study basic sports humanities knowledge, watch sports events, improve their appreciation level and preliminary evaluation ability (Wu, 2010).

Sports skills: The explanation of the skill is that, the exercise system, which can accomplish some tasks through practice, is no exception, but is embodied in the physical exercise program. It also refers to that, the students in the study of some sports skills shall be proficient in at least two or more sports, and then improve their ability by exercise. In addition, it refers to some simple treatment of injuries caused by careless exercise.

\subsection{The Relationship between Lifelong Physical Education and College P.E.}

The college stage is the key moment for the growth and development of young people. Good sports habits can benefit their life, not only promote the physical development in university period, but also promote their mental healthy development. The physical education in colleges and universities is superior to the stages in primary and secondary schools. The college students are confronted with the prophase of social integration, so the university physical education is a bridge, connecting the university sports and the social sports. It is the platform for college students to implement lifelong physical education, with a far-reaching influence. College is the last stop to train students to realize the concept and habit of lifelong physical education. The concept of lifelong sports is the ultimate goal of lifelong education. The implementation of education can be in family, school and society, once you start to persist in life. The lifelong sports thought that we advocate is people-oriented, with a series of related lifelong sports consciousness training of people. The ultimate aim of physical education in colleges and universities is to change the students' sports concept, strengthen their physique, enrich their sports knowledge and cultivate their appreciation and evaluation ability through lifelong P.E. consciousness. It is a responsibility to cultivate students' lifelong sports consciousness, which is beneficial to their physical and mental health, and the healthy body can make contribution (Shi, 2010).

\section{The Importance of Developing the Lifelong Sports Thought in College P.E. Teaching in the New Period}

The college stage is a very important period for the growth and development of young people. At this time, lifelong physical training can make its income infinite. The physical education of the students is simpler than the physical education after entering into the society, and it is an irreplaceable golden period to construct the sports value concept and form the sports habit. The university is the last stop for the youth before entering into the society, and is also the commanding point in the school physical education. It is the bridge that the teenager moves toward the society from the school. The youth can exercise physique, strengthen the physique, train the lifelong sports consciousness, and improve the sports skill in this stage. Therefore, the physical education in colleges and universities to train students' lifelong sports awareness and ability, as its core, is the future of the country to build a solid pillar, and the quality of college students will affect the nation's future.

\subsection{Lifelong Physical Education Is an Objective Requirement of Social Development}

With the progress of science and technology and the mechanization of the process, people's clothing and clothes have a tremendous change, and material and spiritual life enter into a new era together. The computer brings people into the information age. People at home can know the world events. With the progress of science and technology, mechanization 
and automation, thousands of traditional labors are liberated. The living environment changes, more people live in the spacious and bright high-rise buildings. The telephone becomes a reality, and washing machine, vacuum cleaners and other home appliances free the people from the bondage of housework. The people almost have no progress in physical labor. The wealth of material brings about the improvement of the diet system, but nutrition surplus becomes a common disease of modern people. With the expansion of the city, the process of rural urbanization has also brought endless troubles to people, such as environmental pollution, ecological imbalance and frequent geological natural disasters. The proble $\mathrm{m}$ of food safety affects human health, and cardio-cerebrovascular disease, cancers, sub-health and other "modern urban diseases" increase dramatically. To stay away from cardiovascular disease and maintain physical and mental health, the first choice is to carry out lifelong physical exercise. Sports can not only keep fit, but also improve the quality of life (Shi, 2010; Zhang \& Chen, 2010).

In short, from the social point of view, it can be said that "the body is the cost of life". Physical exercise can not only improve the body resistance, reduce the incidence of disease, but also prolong human life. Sports have many advantages. And bodybuilding can make us maintain a vibrant body with good shape, and have healthy bodies to enjoy life better.

\subsection{The Development of Lifelong Physical Education Is the Intrinsic Need of Modern Lifestyles}

The progress of science and technology changed people's way of life, and mechanization liberates the labor force. Different social forms determine different lifestyles, and the traditional way of life in a short period of 30 years has a fundamental change. The affluence of matter, the affluence of life, and people's spiritual life also need to keep pace with the times. The function of sports affirms that sports can enrich people's spiritual life, maintain a person's physical and mental health, improve people's living quality, enhance the physical quality of people, and thus improve the overall qualities of people.

\subsection{The Development of Lifelong Education Is the Meaning of the Training of P.E. Major in the New Period}

The aim of educational reform is to cultivate talents to have all-round development for the motherland. The data show that, the average life expectancy of Chinese intellectuals is only 58.52 years, which is less than 10 years for other professionals, and the health problems of intellectuals seriously affect our country's modernization process. In 1995, the China Sports Daily conducted a survey of highly educated people, $90 \%$ of whom did not have the awareness or action of physical exercise. This is directly related to the traditional teaching concept. We should strengthen the university physical education, cultivate the ideological consciousness of lifelong sports and change the habit of people who don't exercise fundamentally, in order to prolong the life of Chinese.

\subsection{Lifelong Physical Education Is the Key to Promote the Reform of Physical Education in Colleges and Universities in the New Period}

The aim of physical education is to cultivate the socialist successors with physical and mental health, and the foundation is to strengthen the students' physique. The curriculum arrangement of colleges and universities is stipulated, so it is necessary for college students to spend more extra-curricular time in physical exercise. Taking physical exercise as the main, supplemented by the reasonable collocation of the diet, as well as the regular life, the growth and development of college students will be of no problem. And the duty of college P.E. teaching is to strengthen the physique. The most important thing is to train the students ' lifelong sports consciousness and habit. Therefore, the ultimate aim of physical education in colleges and universities should be guided by the thought of lifelong physical education. The physical education in colleges and universities is not only to ensure the students' exercise during the school period, but also prepare them for entering into the society. The students should take physical exercise consciously and voluntarily 


\section{References}

Lin, S. Y., \& Ke, H. F. (2008). The Conception of Establishing the Lifelong Education System for P.E. Teachers in Colleges and Univers ities. Journal of Inner Mongolia Normal University (Educational Science Edition), 1, 17-19.

Shi, D. M. (2010). Problems and Countermeasures in the Continuing Education of P.E. Teachers in Colleges and Universities. Social Science, 1, 7-11.

Wu, X. X. (2010). On the Construction of Lifelong Education System of Teachers under the Concept of Lifelong Education. Continuing Education Research, 3, 23-25.

Zhang, T. L., Chen, X. L. (2010). A Probe into the Professionalization of the Continuing Education of P.E. Teachers in Colleges and Universities. Scientific and Technological Information, 4, 76-79. 